\title{
最近の表面処理技術の動向
}

\author{
河田一喜*
}

\section{Trend of Recent Surface Treatment Technology}

\author{
Kazuki Kawata
}

\section{Synopsis}

The trend of recent surface treatment technology is reviewed. Various kinds of hard coating processes such as TRD, CVD, PVD and PCVD have been applied to dies and molds. As a recent trend of the surface treatment technology for dies and molds, a low-temperature process has been desired from a viewpoint of deformation and change in dimension, and a coating process for dies and molds of complicated geometry has become important. Furthermore, the duplex process (diffusion-hardening treatment + hard coating) has been used for prolongation of dies and molds lives.

The PCVD process has good film adhesion and good throwing power at low temperatures, and it can perform the duplex process continuously. Consequently, the PCVD process has been widely applied to dies and molds. It is expected that the nano-composite films of TiAlSiCNO system and the DLC films by the PCVD realize lubricant-free cold pressing and cold forging and lubricant-less warm and hot working.

\section{1 ・はじめに}

表面処理としては，表１に示すように各種の方法がある が, 金型に適用できるプロセスとしては，室化，硼化，浸 硫窒化に代表される拡散処理法と湿式メッキの硬質クロ ムメッキや無電解ニッケルメッキ, PVD(Physical Vapor Deposition)，CVD(Chemical Vapor Deposition)に代表される 被覆処理法とがある .

金型には，冷間加工用金型 , プラスチック金型, 熱間加 工用金型と多くの種類があり, 要求される特性が異なるた め, 表面処理も使い分ける必要がある.また，2つの表面 処理を複合して適用する場合もある。

最近の傾向としては，寸法精度が厳しい金型が多くなっ ているため，なるべく低温で処理可能なプロセスが採用さ れることが多くなっている．また，低温処理であっても， 高温処理なみの金型耐久性が要求されることも多い.

弚こで,本稿では, 各種金型に多く適用されている硬質 皮膜被覆法である TRD(Thermo Reactive Deposition and Diffusion)法, CVD法, PVD法およびPCVD(Plasma-Enhanced
Chemical Vapor Deposition) 法の処理方法, 膜種, 特性, 応 用例などについて紹介する．

\section{2 . 各種硬質皮膜被覆法の特徵}

各種金型に適用されている各種硬質皮膜被覆法の特徵 の比較を表 2 に示す .

\section{1 TRD 法}

豊田中央研究所で開発された熱反応析出拡散法 (TRD 法) は, 別名 TD プロセス (Toyota Diffusion Coating Process) とも呼ばれており，ホウ砂 $\left(\mathrm{Na}_{2} \mathrm{~B}_{4} \mathrm{O}_{7}\right)$ やハロゲン化物か らなる溶融塩浴に, 主に炭化物形成元素を含む金属や酸化 物の粉末を添加し，乥こに炭素を含む品物を浸漬，保持す ることで, 品物の表面に炭化物層（主に VC）を被覆する 方法である . 処理炉は図 11)に示すように外熱加熱式で， $900 \sim 1050{ }^{\circ} \mathrm{C}$ に保持された溶融塩浴中に 30 分から 10 時 間浸漬後, 塩浴から取り出し直接焼入れを行うものであ る. 炭化物の生成速度は鋼種により異なるが, 最大厚み $20 \mu \mathrm{m}$ 程度であり，処理後に再加熱焼入れを必要とする CVD 法に比べ装置的に有利である. 新しい方法として，

*オリエンタルエンヂニアリング(株研究開発部 , 工博 (Dr., Eng., Research \& Development Division, Oriental Engineering Co., Ltd.) 
表 1 表面処理の種類と分類

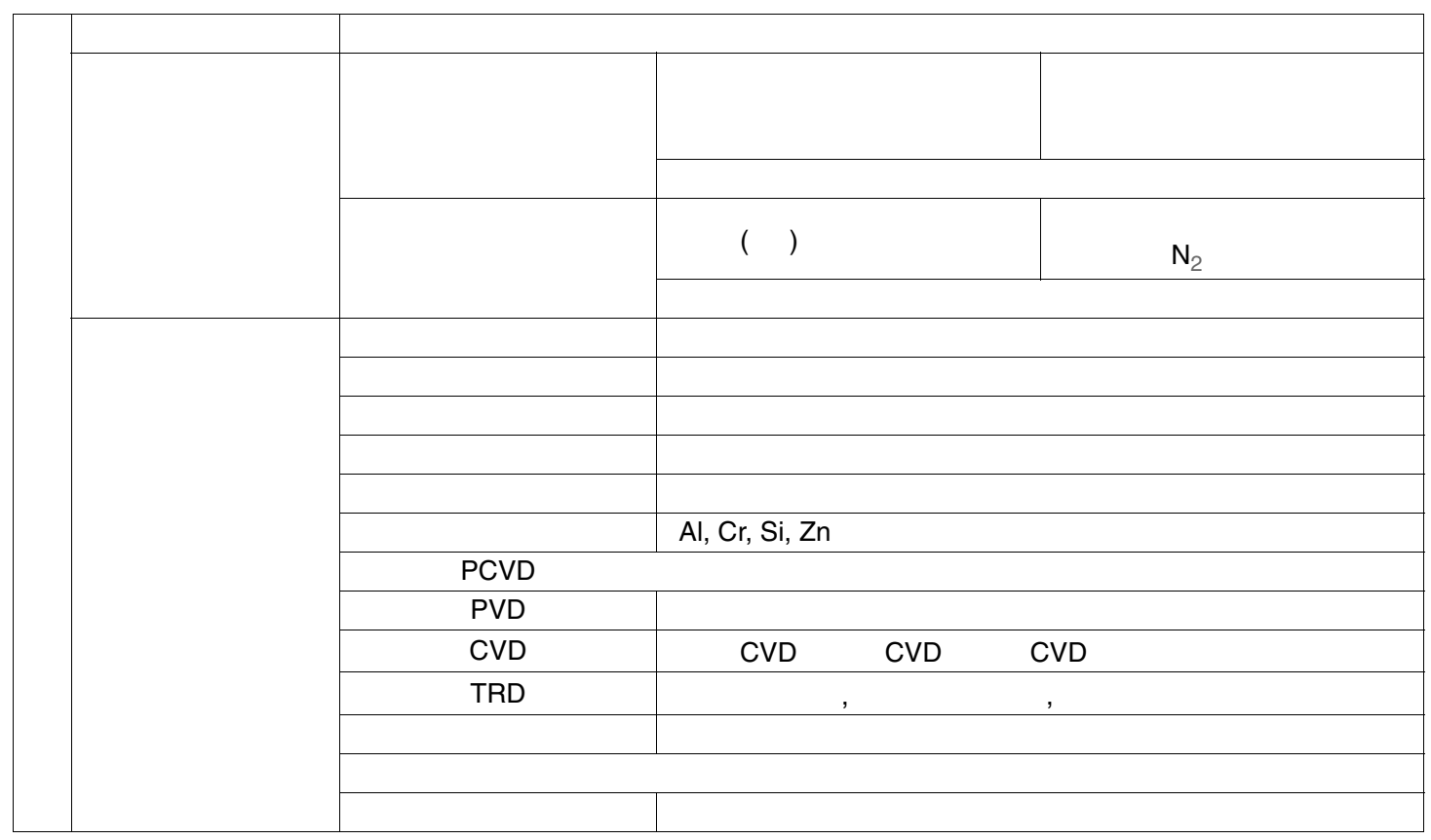

表 2 各種硬質皮膜被覆法の特徵の比較 ${ }^{2)}$

\begin{tabular}{|c|c|c|c|c|c|c|c|c|}
\hline \multirow{2}{*}{ 比較項目 } & \multirow{2}{*}{ PCVD } & \multirow{2}{*}{ PVD } & \multicolumn{3}{|c|}{ CVD } & \multicolumn{3}{|c|}{ TRD } \\
\hline & & & 低温 CVD & 中温 CVD & 高温 CVD & 低温 TRD & 流動層 TRD & 高温 TRD \\
\hline 皮膜 & $\begin{array}{c}\text { TiN, TiCN, } \\
\text { TiAIN, } \\
\text { TiAISiCNO, } \\
\text { DLC }\end{array}$ & $\begin{array}{l}\text { TiN, TiCN, } \\
\text { TiAIN, CrN, } \\
\text { DLC }\end{array}$ & $\mathrm{W}_{2} \mathrm{C}$ & TiCN & $\begin{array}{l}\text { TiN, TiCN, } \\
\mathrm{TiC}, \mathrm{Al}_{2} \mathrm{O}_{3}\end{array}$ & $\mathrm{Cr}(\mathrm{CN})$ & VC & VC \\
\hline 処理方法 & プラズマ反応 & プラズマ反応 & 熱化学反応 & 熱化学反応 & 熱化学反応 & $\begin{array}{l}\text { 塩浴中におけ } \\
\text { る熱化学反応 }\end{array}$ & $\begin{array}{l}\text { 流動層中にお } \\
\text { ける熱化学反 } \\
\text { 応 }\end{array}$ & $\begin{array}{l}\text { 塩浴中におけ } \\
\text { る熱化学反応 }\end{array}$ \\
\hline 処理温度 ( ${ }^{\circ} \mathrm{C}$ ) & $200 \sim 600$ & $200 \sim 600$ & $500 \sim 600$ & $700 \sim 900$ & 約 1000 & $500 \sim 650$ & 約 1000 & 約 1000 \\
\hline 処理圧力 (Torr) & $10^{-2} \sim 10$ & $10^{-3} \sim 10^{-4}$ & $50 \sim 760$ & $50 \sim 760$ & $50 \sim 760$ & 760 & 760 & 760 \\
\hline 密 着 性 & () & $\triangle$ & $\triangle$ & () & () & $\bigcirc$ & () & (2) \\
\hline 緻 密 性 & (a) & 0 & $\triangle$ & $\triangle$ & $\triangle$ & $\triangle$ & $\triangle$ & $\triangle$ \\
\hline つき回り性 & 0 & $\triangle$ & (2) & (a) & (a) & (a) & (2) & (a) \\
\hline 寸法精度 & (a) & (a) & (a) & $\triangle$ & $\triangle$ & (a) & $\triangle$ & $\triangle$ \\
\hline 局部被覆 & (a) & () & $\triangle$ & $\triangle$ & $\triangle$ & $\triangle$ & $\triangle$ & $\triangle$ \\
\hline 重量物の処理 & (a) & $\triangle$ & (2) & (a) & (a) & (a) & 0 & (a) \\
\hline 作業環境 & (2) & (a) & $\triangle$ & $\triangle$ & $\triangle$ & $\triangle$ & $\triangle$ & $\triangle$ \\
\hline ランニングコスト & (2) & (a) & $\triangle$ & $\triangle$ & $\triangle$ & 0 & $\triangle$ & () \\
\hline 前 処 理 & 不要 & Ti コート必要 & $\begin{array}{l}\mathrm{Ni} \text { 系めっき } \\
\text { 必要 }\end{array}$ & 不要 & 不要 & 窒化処理必要 & 不要 & 不要 \\
\hline
\end{tabular}

図 2 に示すような流動層炉 1) を利用した技術も開発され ている.この方法は,主に炭化物形成元素を含む金属粉末 とアルミナ粉末とから成る処理剂に塩化アンモニウムな どの反応促進剂を添加し，アルゴンガスで処理剂を流動化 させながら品物を装入し，所定時間保持し溶融塩法と同樣 の炭化物などを品物表面に被覆する方法である.この方法 は溶融塩法のようにソルトの付着がないため, CVD 法と 同樣に被覆後の洗浄が不要となる．また，被覆から焼入
れ, 焼戻しまでの工程の自動化が可能になる．ただ, 溶融

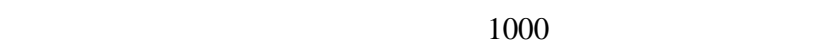
型の変形, 変寸には注意が必要である.一方, 膜の密着性 とつき回り性は優れている .

最近では, あらかじめ室化した鋼材を低温域（500〜 $600{ }^{\circ} \mathrm{C}$ ) で溶融塩法により $\mathrm{Cr}$ 炭室化物層を被覆できる低 温 TRD 法も開発されている ${ }^{2)}$. 

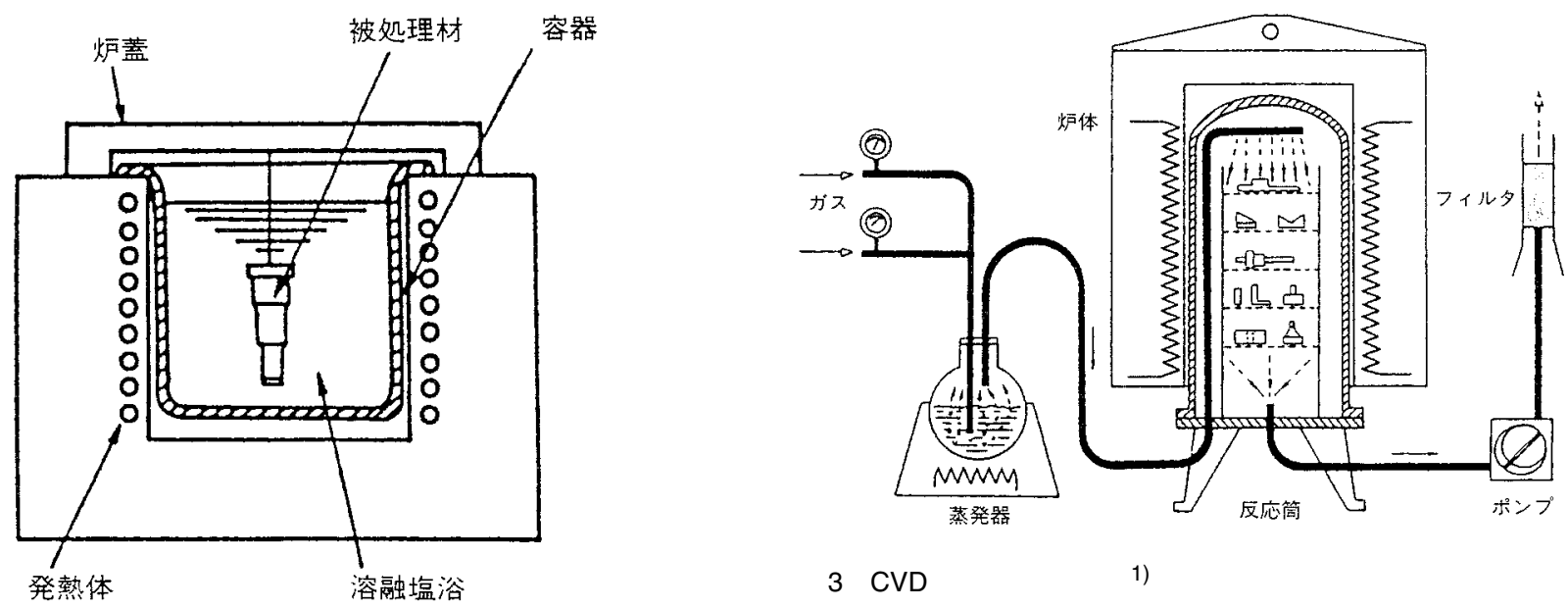

図 3 CVD 法の装置概略図 ${ }^{1)}$

图 1 溶融塩式 TRD 法の装置概略図 ${ }^{1)}$

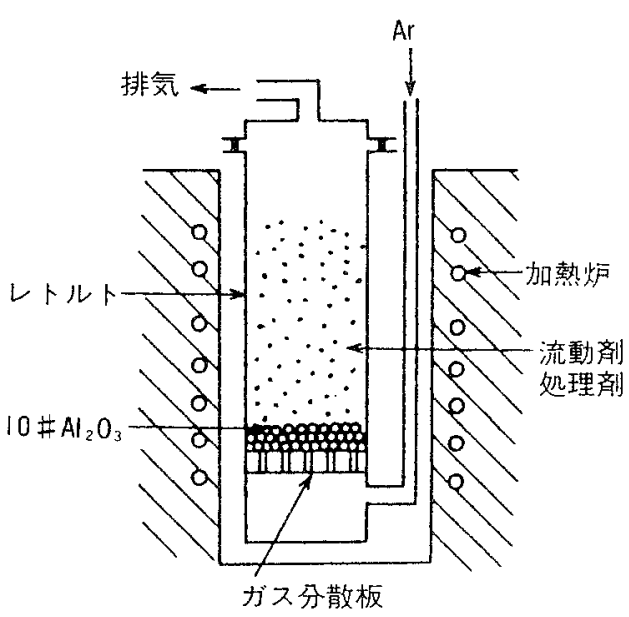

図 2 流動層炉式 TRD 法の装置概略図 ${ }^{1)}$

\subsection{CVD 法}

化学蒸着 (CVD) 法は, ヨーロッパから導入された技術 で, 図 $3^{1)}$ に示すように約 $1000{ }^{\circ} \mathrm{C} に$ 加熱された金属容器中 に Tiや $\mathrm{Al}$ などの八ロゲン化物の蒸気，炭化水素, 窒素お よび水素ガスなどを流し，常圧または減圧下で TiC, TiN, $\mathrm{TiCN}, \mathrm{Al}_{2} \mathrm{O}_{3}$ などのセラミックスを被覆する技術である． この方法では, 被覆後の冷却速度が遅く, 鋼などでは焼入 れが不十分なため, 再度真空炉などで再加熱焼入れを行う 必要がある.また，装置的には排ガス処理装置が必要であ り，品物を入れて出すまでの時間が長い .この方法は TRD 法と同樣に処理温度が高いため金型の変形,変寸には注意 が必要である.ただ, 膜の密着性とつき回り性は優れてい るため高面圧のかかる金型には向いている .

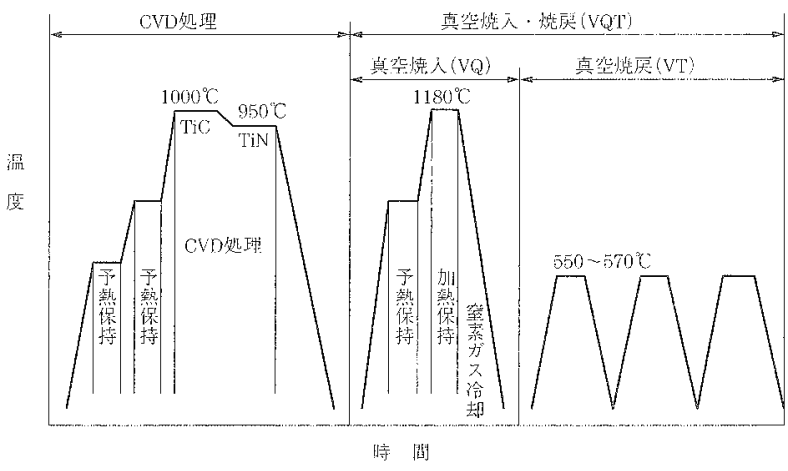

図 4 高速度工具鋼の CVD 処理ヒートプロセス ${ }^{4)}$

表 3 にCVD 処理の代表的な化学反応例 ${ }^{4)}$ を示す .また， 表 4 にCVD で作製される代表的なコーティング膜の物理 的性質 ${ }^{4)}$ を示す .さらに ,図 4 に高速度工具鋼に TiC/TiCN/ TiN 多層膜を成膜する場合のヒートプロセス ${ }^{4)}$ を示す .低 温 CVD 法は, $500 \sim 600{ }^{\circ} \mathrm{C}$ という低温で $\mathrm{W}_{2} \mathrm{C}$ という膜を 被覆できるため, 変形, 変寸は少ないという利点はある が，下地処理として無電解 $\mathrm{Ni}$ メッキ層を被覆しているた め高面圧のかかる金型には密着性に関して問題がある .

\subsection{PVD 法}

PVD 法は真空蒸着，スパッタリング (Sputtering)，イオ ンプレーティング (Ion Plating) という 3 つの物理蒸着法の 総称で,金型用には主にイオンプレーティングが使われて いる.このイオンプレーティングの中で代表的なアーク式 イオンプレーティング (Arc Ion Plating, AIP) 装置と HCD(Hollow Cathode Discharge, ホロカソード放電) 式イオ ンプレーティング装置の概略4)を図 5 に示す .

まず,アーク式イオンプレーティングは, 固体金属(ター 
ゲット)を陰極としアーク放電を起こすことにより溶融蒸 発させ金属イオンを真空中に放出する .一方 ,バイアス電 圧を被コーティング物に印加することにより，金属イオン は加速され反応ガスとともに,被コーティング物の表面に 堆積する .この方式は次のような長所がある .すなわち ，

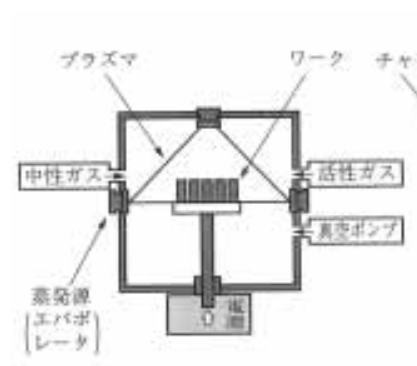

(アークブラズマ方式)

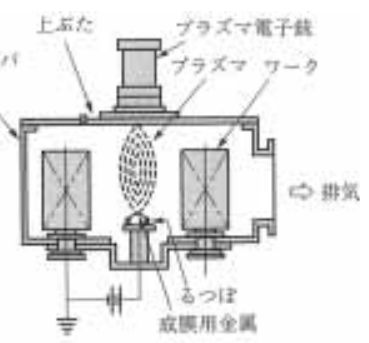

( $H C D$ 方式)
図 5 代表的な PVD 装置概略 4)
(1)処理温度が $200{ }^{\circ} \mathrm{C}$ 程度と低い温度でもコーティングで きる．(2)合金ターゲットを使えば TiAIN 膜などの金属元素 を2つ以上含む膜を作製できる.(3)ターゲットが壁にある ため中心に被処理物をセットでき,大物から小物まで処理 できる.一方, 他の方式に比べてアーク放電によるドロッ プレットが発生するため, 表面欠陥の多い膜になり精密金 型には不向きであるという短所がある.

HCD 式イオンプレーティングは, プラズマ電子銃によ りるつぼ中の金属を溶融蒸発させ, 蒸発した金属蒸気と反 応ガスは電子銃からの電子によりイオン化され,バイアス 電圧を印加された被コーティング物の表面に化合物膜と して堆積する この方式はアアーク式イオンプレーティング に比べて，表面欠陌が少なく，表面粗さの小さいスムース な膜ができる長所がある.一方, 処理温度がアーク式に比 べて $400 \sim 600{ }^{\circ} \mathrm{C}$ と比較的高く，また，TiAlN 膜のような

表 3 CVD 処理の代表的な化学反応例 ${ }^{4)}$

\begin{tabular}{|c|c|}
\hline 被覆材 & 応 \\
\hline TiC & 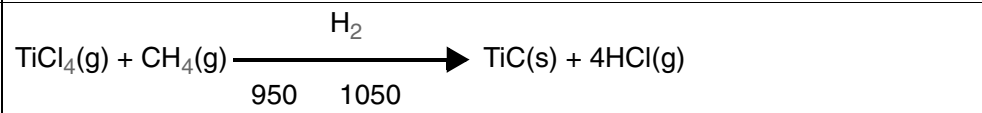 \\
\hline TiN & $\mathrm{TiCl}_{4}(\mathrm{~g})+1 / 2 \mathrm{~N}_{2}(\mathrm{~g}) \underset{850 \sim 1000^{\circ} \mathrm{C}}{\stackrel{\mathrm{H}_{2}}{\longrightarrow}} \mathrm{TiN}(\mathrm{s})+4 \mathrm{HCl}(\mathrm{g})$ \\
\hline $\mathrm{Ti}(\mathrm{CN})$ & $\begin{array}{l}\mathrm{TiCl}_{4}(\mathrm{~g})+\mathrm{CH}_{4}(\mathrm{~g})+1 / 2 \mathrm{~N}_{2}(\mathrm{~g}) \underset{900 \sim 1050{ }^{\circ} \mathrm{C}}{\longrightarrow} \mathrm{Ti}(\mathrm{CN})(\mathrm{s})+4 \mathrm{HCl}(\mathrm{g}) \\
\mathrm{MT}-\mathrm{CVD} \\
2 \mathrm{TiCl}_{4}(\mathrm{~g})+\mathrm{R}-\mathrm{CN}(\mathrm{g}) \underset{700 \sim 900^{\circ} \mathrm{C}}{\longrightarrow} 2 \mathrm{Ti}(\mathrm{CN})(\mathrm{s})+\mathrm{HCl}(\mathrm{g})+\mathrm{RCl}(\mathrm{g})\end{array}$ \\
\hline $\mathrm{Cr}_{7} \mathrm{C}_{3}$ & 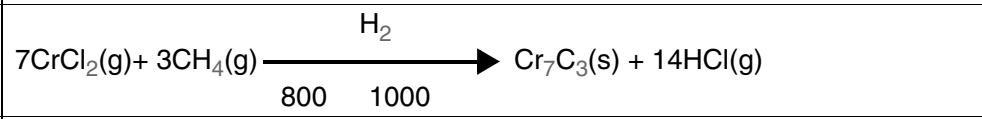 \\
\hline $\mathrm{Al}_{2} \mathrm{O}_{3}$ & $2 \mathrm{AlCl}_{3}(\mathrm{~g})+3 \mathrm{CO}_{2}(\mathrm{~g})+3 \mathrm{H}_{2}(\mathrm{~g}) \underset{950 \sim 1050^{\circ} \mathrm{C}}{\longrightarrow} \mathrm{Al}_{2} \mathrm{O}_{3}(\mathrm{~s})+3 \mathrm{CO}(\mathrm{g})+6 \mathrm{HCl}(\mathrm{g})$ \\
\hline
\end{tabular}

MT: Moderate-Temperature (g): ガス , (s): 固体

表 4 CVD で作製される代表的なコーティング膜の物理的性質 4)

\begin{tabular}{|c|c|c|c|c|}
\hline $3^{2}$ & 炭化物 & 窒化物 & 炭窒化物 & 酸化物 \\
\hline 物理的性質 & $\mathrm{TiC}$ & $\mathrm{TiN}$ & TiCN & $\mathrm{Al}_{2} \mathrm{O}_{3}$ \\
\hline 硬さ (HV) & $3000 \sim 4000$ & $1900 \sim 2400$ & $2600 \sim 3200$ & $2200 \sim 2600$ \\
\hline 溶融点 $\quad\left({ }^{\circ} \mathrm{C}\right)$ & 3160 & 2950 & 3050 & 2040 \\
\hline 密度 $\quad\left(\mathrm{g} / \mathrm{cm}^{3}\right)$ & 4.92 & 5.43 & 5.18 & 3.98 \\
\hline $\begin{array}{l}\text { 熱膨張係数 }\left(/{ }^{\circ} \mathrm{C}\right) \\
\left(200 \sim 400{ }^{\circ} \mathrm{C}\right)\end{array}$ & $7.8 \times 10^{-6}$ & $8.3 \times 10^{-6}$ & $8.1 \times 10^{-6}$ & $7.7 \times 10^{-6}$ \\
\hline 電気抵抗 $\left(20^{\circ} \mathrm{C}\right)(\Omega \mathrm{cm})$ & $8.5 \times 10^{-5}$ & $2.2 \times 10^{-5}$ & $5.0 \times 10^{-5}$ & $10^{14}$ \\
\hline 弾性率 $\quad\left(\mathrm{kg} / \mathrm{mm}^{2}\right)$ & $4.48 \times 10^{4}$ & $2.56 \times 10^{4}$ & $3.52 \times 10^{4}$ & $3.90 \times 10^{4}$ \\
\hline 摩擦係数 $\quad(\mu)$ & 0.25 & 0.49 & 0.37 & 0.15 \\
\hline 適正被覆厚さ $(\mu \mathrm{m})$ & $2 \sim 8$ & $2 \sim 8$ & $2 \sim 10$ & $1 \sim 3$ \\
\hline
\end{tabular}


金属元素を2つ以上含む膜は作製困難である.さらに，装 置中心にるつぼがあるため，小物の処理にしか使えない．

表 5 にはPVD で工業的に可能なコーティング皮膜の特 性および用途4)を示す．

\subsection{PCVD法 (プラズマ CVD 法)}

TRD 法および CVD 法は, 膜の密着性とつき回り性に優 れているが, 処理温度が約 $1000{ }^{\circ} \mathrm{C}$ と高いため金型の変形， 変寸が生じやすい，一方，PVD 法は低温処理であるため 金型の变形, 変寸の問題はないが, TRD 法および CVD 法 に比べて膜の密着性およびつき回り性が劣っている.弚の ため,高面圧のかかる金型や複雑形状をした金型の処理に は適用できない .

PCVD 法は，CVD 法と PVD 法の両者の欠点を克服し， 長所のみを融合した新しいプロセスである．すなわち， PCVD 法は低温で密着性の良い皮膜をつき回り良く被覆 できるため，各種の金型に応用可能である. 最近では， PCVD 法による DLC(S-DLC) 膜や TiAlSiCNO 系ナノコン ポジット膜も開発され プレス加工の無潤滑化やダイカス ト ,チクソモールディングにおける離型剂レス化に大きく 貢献している.
図 6 に量産型 PCVD 装置の概略图 5) を示す．この装置 の構成は，外熱ヒーター，真空排気系，パルス DC 電源，

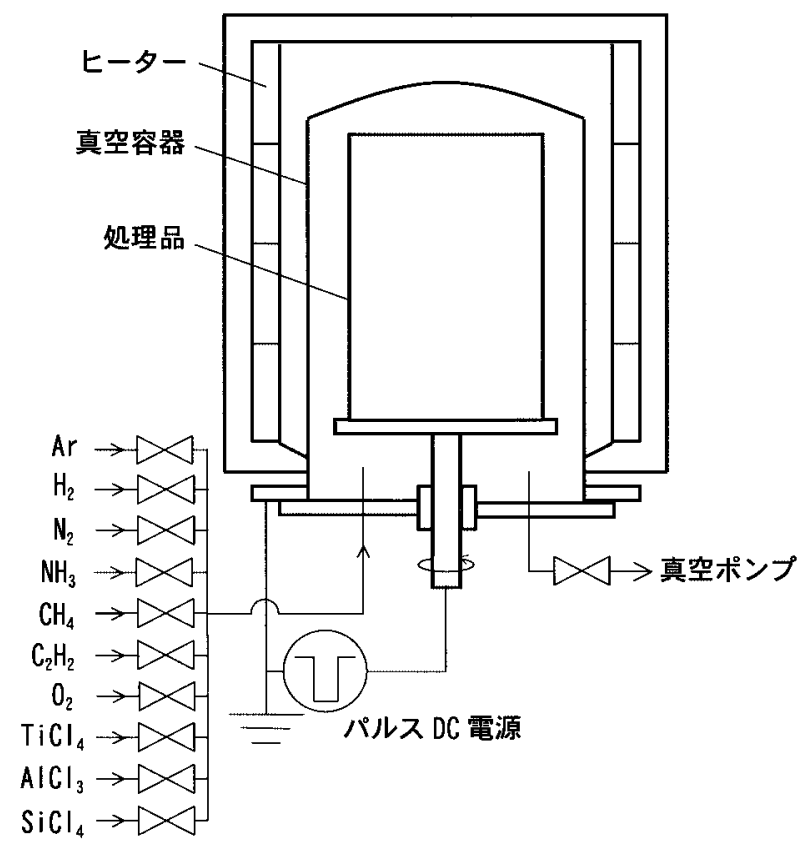

図 6 量産型 PCVD 装置概略図 ${ }^{5)}$

表 5 PVD で工業的に可能なコーティング皮膜の特性および用途 4$)$

\begin{tabular}{c|c|c|c|c|c|c|c|l}
\hline 膜種 & 色調 & 硬度 $(\mathrm{HV})$ & 摩擦係数 & 耐食性 & 耐酸化性 & 耐摩耗性 & 耐焼付性 & \multicolumn{1}{|c}{ 途 } \\
\hline $\mathrm{TiN}$ & 金色 & $2000 \sim 2400$ & 0.45 & $\bigcirc$ & $\bigcirc$ & $\bigcirc$ & $\bigcirc$ & 切削工具, 金型, 装飾品 \\
\hline $\mathrm{ZrN}$ & ホワイトゴールド & $2000 \sim 2200$ & 0.45 & $\bigcirc$ & $\triangle$ & $\triangle$ & $\triangle$ & 装飾品 \\
\hline $\mathrm{CrN}$ & 銀白色 & $2000 \sim 2200$ & 0.30 & $\bigcirc$ & $\bigcirc$ & $\bigcirc$ & $\bigcirc$ & 機械部品, 金型 \\
\hline $\mathrm{TiC}$ & 銀白色 & $3200 \sim 3800$ & 0.10 & $\triangle$ & $\triangle$ & $\bigcirc$ & $\bigcirc$ & 切削工具 \\
\hline $\mathrm{TiCN}$ & バイオレット〜灰 & $3000 \sim 3500$ & 0.15 & $\triangle$ & $\triangle$ & $\bigcirc$ & $\bigcirc$ & 切削工具, 金型 \\
\hline $\mathrm{TiAIN}$ & バイオレット〜黑 & $2300 \sim 2500$ & 0.45 & $\bigcirc$ & $\bigcirc$ & $\bigcirc$ & $\bigcirc$ & 切削工具, 金型, 装飾品 \\
\hline $\mathrm{Al}_{2} \mathrm{O}_{3}$ & 透明〜灰色 & $2200 \sim 2400$ & 0.15 & $\bigcirc$ & $\bigcirc$ & $\bigcirc$ & $\bigcirc$ & 絶縁膜, 機能膜 \\
\hline $\mathrm{DLC}$ & 灰色〜黑色 & $3000 \sim 5000$ & 0.10 & $\bigcirc$ & $\bigcirc$ & $\bigcirc$ & $\bigcirc$ & 切削工具, 機能膜, 金型 \\
\hline
\end{tabular}

表 6 PCVD 法による各種硬質皮膜の特性 ${ }^{5)}$

\begin{tabular}{|c|c|c|c|c|c|c|c|}
\hline & TiN & TiCN & TiAIN & TiAICN & TiAION & TiAISiCNO & DLC \\
\hline コーティング温度 $\left({ }^{\circ} \mathrm{C}\right)$ & $450 \sim 550$ & $450 \sim 550$ & $450 \sim 550$ & $450 \sim 550$ & $450 \sim 550$ & $450 \sim 550$ & $\leqq 200$ \\
\hline 硬さ (HV) & $2000 \sim 2300$ & $2300 \sim 3500$ & $2300 \sim 3500$ & $2300 \sim 4000$ & $1400 \sim 2300$ & $1500 \sim 5000$ & $1000 \sim 5000$ \\
\hline 色 & ゴールド & $\begin{array}{c}\text { ピンク〜シル } \\
\text { バーグレイ }\end{array}$ & $\begin{array}{c}\text { バイオレット } \\
\text { ～グレイ }\end{array}$ & $\begin{array}{c}\text { バイオレット } \\
\text { ～グレイ }\end{array}$ & ブラック & $\begin{array}{c}\text { バイオレット } \\
\text { ～ブラック }\end{array}$ & ブラック \\
\hline 膜構造 & 単層 & $\begin{array}{l}\text { 多層, 傾斜組 } \\
\text { 成層 }\end{array}$ & $\begin{array}{l}\text { 多層, 傾斜組 } \\
\text { 成層 }\end{array}$ & $\begin{array}{l}\text { 多層, 傾斜組 } \\
\text { 成層 }\end{array}$ & $\begin{array}{l}\text { 多層, 傾斜組 } \\
\text { 成層 }\end{array}$ & $\begin{array}{l}\text { 多層, 傾斜組 } \\
\text { 成層 (ナノココ } \\
\text { ンポジット) }\end{array}$ & ( 非晶質 ) \\
\hline 最高使用温度 $\quad\left({ }^{\circ} \mathrm{C}\right.$ ) & 600 & 500 & 800 & $750 \sim 800$ & 850 & $750 \sim 1000$ & 450 \\
\hline 膜厚 $(\mu \mathrm{m})$ & $1 \sim 5$ & $1 \sim 5$ & $1 \sim 5$ & $1 \sim 5$ & $1 \sim 5$ & $1 \sim 5$ & $0.1 \sim 10$ \\
\hline 摩擦係数 & $0.1 \sim 0.5$ & $0.1 \sim 0.2$ & $0.1 \sim 0.5$ & $0.1 \sim 0.5$ & $0.1 \sim 0.5$ & $0.1 \sim 0.5$ & $0.02 \sim 0.2$ \\
\hline
\end{tabular}


各種ガス供給系, コンピュータ制御系より成る、ワーク テーブルを回転させることにより，膜厚分布を良くしてい る.また，有効処理寸法は $\varphi 460 \times \mathrm{H} 800 \mathrm{~mm}$ と大きく， $200 \mathrm{~kg}$ 以上の金型の処理にも対応できる構造になってい る.PCVD 法はガスの種類を変えれば各種の膜が作製で き，単層膜だけでなく多層膜や傾斜組成膜も作製しやす い.また，室化・浸炭などの各種拡散硬化処理あるいは拡 散硬化処理 + 硬質皮膜という複合処理が 1 つの装置で, 真 空を破らずに1回の工程でできる

表 6 に PCVD 法により作製した各種硬質皮膜の特性 ${ }^{5)}$ を示す．

\section{PCVD 法の応用}

プレス，鍛造などの冷間加工用金型で特に負荷のかかる ものには，従来高温 CVD 法や高温 TRD 法のような高温 プロセスが多く使われてきた .また，低温処理である PVD 法は,変寸は少ないが,負荷のかかる金型には膜の密着性 の観点から乥の適用には問題があった .

PCVD 法は, 低温処理で膜の密着性が優れているという ことで，これまで高温 CVD 法や高温 TRD 法が使われて いた金型にも多く適用され，効果を発揮している.表7に
冷間加工用金型に対する PCVD 適用効果例 5) を示す . こ の表からもわかるように ,PCVD 法は従来の高温プロセス と同等以上の型寿命を達成している.このように，工具鋼 の焼戻し温度以下の低温処理である PCVD 法は型寿命延 長の効果だけでなく，法管理上も高温プロセスに比べて 有利で, また ,再コーティングして何回でも型を使えると いうトータルメリットがある．

TiAlN膜は, 耐摩耗性と耐酸化性を兼ね備えているため， ドライ切削用の有力な膜として PVD 法により被覆されて いる．しかし，PVD 法は高真空処理であるため，膜のつ き回り性が悪く,複雑形状をした金型への応用が困難であ る。

一方，PCVD 法は PVD 法に比べて膜のつき回り性が良 く,ガス組成を切り替えることにより多層膜や傾斜組成膜 を形成できるため，密着性良く被覆できる．また，PCVD 法は真空を破らずに 1 回の工程で 1 つの装置の中で拡散層 $+(\mathrm{Ti}, \mathrm{Al}) \mathrm{N}$ 系多層膜を形成させることもできる.弚のため , PCVD 法による拡散層 +(Ti, Al)N 系多層膜は, アルミダイ カスト型や押し出し型などの熱間で使用される金型に多 く適用されている.表 8 に PCVD による $(\mathrm{Ti}, \mathrm{Al}) \mathrm{N}$ 系多層 膜の応用例 ${ }^{6)}$ を示す。

表 7 冷間加工用金型に対する PCVD 適用効果例 ${ }^{5)}$

\begin{tabular}{|c|c|c|}
\hline 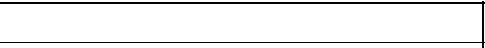 & 金型材質 & 耐久性効果 \\
\hline $\begin{array}{l}\text { 冷間穴抜きパンチ } \\
\text { (被加工材 : S12C, 肉厚 } 3.1 \mathrm{~mm} \text { ) }\end{array}$ & SKH51 & 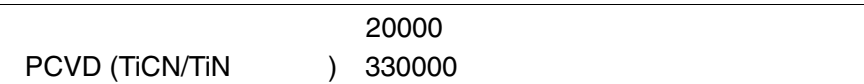 \\
\hline $\begin{array}{l}\text { 冷間圧造ダイ } \\
\text { (被加工材: ボールジョイント部ソ } \\
\text { ケット SCM } 415, \text { 肉厚 } 5 \mathrm{~mm} \text { ) }\end{array}$ & SKH51 & $\begin{array}{l}\cdot \text { CVD (TiC) } \\
\cdot \text { PCVD (TiCN/TiN 多層膜 }): 48000 \text { 個 } \\
\cdot 48500 \text { 個 }\end{array}$ \\
\hline $\begin{array}{l}\text { 冷間成形ダイ } \\
\text { (被加工材 : SUS304, 肉厚 } 1.6 \mathrm{~mm} \text { ) }\end{array}$ & SKD11 & $\begin{array}{ll}\cdot \operatorname{TRD}(\mathrm{VC}) & : 25000 \text { 個 } \\
\cdot \operatorname{PCVD}(\mathrm{TiCN} / \mathrm{TiN} \text { 多層膜 ) }: 120000 \text { 個 }\end{array}$ \\
\hline $\begin{array}{l}\text { トリミングダイ } \\
\text { (被加工材 : ボルト) }\end{array}$ & 粉末ハイス & $\begin{array}{ll}\cdot \operatorname{CVD} & : 30000 \text { ショット } \\
\cdot \operatorname{PCVD}(\mathrm{TiCN} / \mathrm{TiN} \text { 多層膜 ) }: 61900 \text { ショット }\end{array}$ \\
\hline $\begin{array}{l}\text { 冷間鍛造パンチ } \\
\text { (被加工材 : ボルト) }\end{array}$ & SKH55 & $\begin{array}{ll}\cdot \text { ・ } \text { 未コーティング } & : 45000 \text { 個 } \\
\cdot \text { PVD (TiN) } & : 45000 \text { 個 } \\
\cdot \text { CVD (TiN/TiCN/TiC) } & : 75000 \text { 個 } \\
\cdot \text { PCVD (TiCN/TiN 多層膜 ) }: 150000 \text { 個 }\end{array}$ \\
\hline $\begin{array}{l}\text { 鋼管加工用マンドレル } \\
\text { (被加工材 : SUS304, 肉厚 } 4 \rightarrow 2 \mathrm{~mm} \text { ) }\end{array}$ & 粉末ハイス & $\begin{array}{l}\cdot \operatorname{TRD}(\mathrm{VC}): 530 \text { 本 (再コーティング品は新品の半分以下) } \\
\cdot \text { CVD }: 780 \text { 本 (再コーティング品は新品の半分以下) } \\
\cdot \text { PCVD (TiCN/TiN 多層膜 ) : } 1200 \text { 本 (再コーティング品は } 1815 \text { 本) }\end{array}$ \\
\hline $\begin{array}{l}\text { 座押バーリングパンチ } \\
\text { (被加工材 : SUS304, 肉厚 } 0.5 \mathrm{~mm} \text { ) }\end{array}$ & SKH51 & $\begin{array}{ll}\cdot \operatorname{CVD}(\mathrm{TiC}: 6 \mu \mathrm{m}) & : 15000 \text { ショット } \\
\cdot \operatorname{PCVD}(\mathrm{TiCN} / \mathrm{TiN} \text { 多層膜 }) ： 52000 \text { ショット } \\
\end{array}$ \\
\hline $\begin{array}{l}\text { モーターケース加工用パンチ } \\
\text { (被加工材 : 肉厚 } 1.5 ~ 3.5 \mathrm{~mm} \text { ) }\end{array}$ & DC53 & $\begin{array}{ll}\cdot \text { ・ } & : 60000 \text { ショッットン } \\
\cdot \text { Crメッキ } & : 70000 ~ 80000 \text { ショット } \\
\cdot \text { CVD (TiN/TiCN/TiC) } & : 200000 \text { ショット } \\
\cdot \operatorname{PCVD}(\mathrm{TiCN} / \mathrm{TiN} \text { 多層膜 }) ~ & : 400000 \text { ショット } \\
\end{array}$ \\
\hline
\end{tabular}


兴の他，PCVD 法による $(\mathrm{Ti}, \mathrm{Al}) \mathrm{N}$ 系多層膜は, マグネ ダイカスト型，マグネチクソモールド，アルミや銅合金の 熱鍛型にも応用されている

$\mathrm{PCVD}$ 法による $(\mathrm{Ti}, \mathrm{Al}) \mathrm{N}$ 系膜の特徵をまとめるとつぎ のようになる .

(1) TiN 膜に比へて耐酸化性に優れている.

(2) 工具鋼の焼戻し温度以下という低温処理のため,金型 の変形, 変寸がない .

(3) PVD 法と違って多層膜，あるいは傾斜組成膜を作製 しやすいため，膜の密着性に優れている．

(4) PVD法と違って膜のつき回り性に優れているため, 複 杂倠形状をした各種金型に応用できる．

(5) 拡散硬化処理と ( $\mathrm{Ti}, \mathrm{Al}) \mathrm{N}$ 系多層膜を 1 回の工程で形 成できるため，金型の寿命向上が期待できる .

特に,アルミダイカスト金型に対しては, 耐ヒート チェックと耐溶損の両方に効果を発揮できる .
ダイカスト ,チクソモールディングの業界において金型 への離型剂の噴霧を廃止できれば環境上および製品品質 上からも大きなメリットがある PCVD法は拡散層+TiAlN 系多層膜を低温でつき回り良くダイカスト金型などに形 成できるため, 1 つの処理で耐溶損性，耐溶着性だけでな く耐ヒートチェック性も併せ持たせることができる .この ような各種特性に優れた TiAlN 系膜に Si を添加すること により TiAlSiCNO 系多層膜を PCVD 法により作製した . この TiAlSiCNO 膜はナノオーダーで結晶相と非晶質相が コンポジット化されていると考えられる.図 7 に PCVD 法による TiN/TiAIN/TiAlSiCNO 多層膜の断面 SEM 像 ${ }^{6}$ をを 示す. 最表層の TiAlSiCNO 膜はアモルファス状の緻密な 組織であることがわかる.また , この膜はアルミ合金溶湯 中における溶損試験において，TiAIN 膜より優れた耐溶損 性を示した .さらに, アルミ合金の溶着が最も少なく, 離 型性に優れていることも確認された .この TiAlSiCNO 系

表 $8 \mathrm{PCVD}$ 法による (Ti, Al)N 系多層膜の各種金型に対する効果 ${ }^{6)}$

\begin{tabular}{|c|c|c|c|}
\hline 金型の種類 & 適用品名 & 金型材質 & 適用効果 \\
\hline プラスチック金型 & $\begin{array}{l}\text { 【家電部品】 } \\
\text { ・フェノール樹脂 (20 30％ ガラ } \\
\text { ス擮維入り) } \\
\text { ·樹脂温度 : } 200{ }^{\circ} \mathrm{C}\end{array}$ & HAP40(66HRC) & $\begin{array}{l}\text { 【ハード Cr メッキ】: } 6000 \text { ショットで腐 } \\
\text { 食, 摩耗 } \\
\text { 【PVD, TiN】 : } 10000 \text { ショットで腐食, 摩耗 } \\
\text { 【PCVD, (Ti, Al)N 系多層膜】: } 18000 \text { ショッ } \\
\text { トで一部腐食, 摩耗 }\end{array}$ \\
\hline プレス金型 & $\begin{array}{l}\text { 【自動車部品】 } \\
\text { 被加工材 } \\
\cdot \text { ·材質 : S35C } \\
\cdot \text { ·肉厚 : } 2.6 \mathrm{~mm}\end{array}$ & YXR33(56HRC) & $\begin{array}{l}\text { 【PVD, TiN】 : } 750 \text { ショット } \\
\text { 【PCVD, (Ti, Al)N 系多層膜】 : } 1700 \text { ショッ } \\
\text { ト以上 }\end{array}$ \\
\hline $\begin{array}{l}\text { アルミダイカスト金型 } \\
\text { (ピン) }\end{array}$ & $\begin{array}{l}\text { 【自動車部品】 } \\
\text { ·溶湯 : ADC12 } \\
\text { ·溶湯温度 : } 700{ }^{\circ} \mathrm{C}\end{array}$ & $\mathrm{DHA}(49 \mathrm{HRC})$ & $\begin{array}{l}\text { 【ガス窒化】 : } 5000 \text { ショットで溶損 } \\
\text { 【PCVD, TiN】 : } 11000 \text { ショットで一部溶損 } \\
\text { 始まる } \\
\text { 【PCVD, (Ti, Al)N 系多層膜】: } 30000 \text { ショッ } \\
\text { トの時点で溶損全くなし }\end{array}$ \\
\hline $\begin{array}{l}\text { アルミダイカスト金型 } \\
\text { (ピン) }\end{array}$ & $\begin{array}{l}\text { 【自動車部品】 } \\
\text { ・溶湯 : ADC14 } \\
\cdot \text { ·溶湯温度 : } 6800^{\circ} \mathrm{C} \\
\cdot \text { 湯口部近傍 }\end{array}$ & SKD61(48HRC) & $\begin{array}{l}\text { 【CVD, TiN/TiCN/TiC】 : 3000 5000 ショッ } \\
\text { トで溶損 } \\
\text { 【PCVD, (Ti, Al)N 系多層膜】 : } 10000 \text { ショッ } \\
\text { トの時点で溶損なし }\end{array}$ \\
\hline $\begin{array}{l}\text { アルミダイカスト金型 } \\
\text { (可動入れ子) }\end{array}$ & $\begin{array}{l}\text { 【自動車部品】 } \\
\cdot \text { 溶湯 : ADC3 } \\
\cdot \text { 溶湯温度 : } 680{ }^{\circ} \mathrm{C}\end{array}$ & DAC55(50HRC) & $\begin{array}{l}\text { 【真空窒化】: } 25000 \text { ショットで溶損 , ヒー } \\
\text { トチェックのため溶接補修 } \\
\text { 【PCVD, (Ti, Al)N 系多層膜】: } 100000 \\
\text { ショットまで溶損 , ヒートチェックなし }\end{array}$ \\
\hline $\begin{array}{l}\text { アルミスクイーズキャスト金型 } \\
\text { (ピン) }\end{array}$ & $\begin{array}{l}\text { 【自動車部品】 } \\
\cdot \text { 溶湯 : ADC14 } \\
\cdot \text { 溶湯温度 : } 800{ }^{\circ} \mathrm{C} \\
\cdot \text { 射出圧力 : } 1250 \sim 1300 \mathrm{~kg} / \mathrm{cm}^{2}\end{array}$ & SKD61(48HRC) & $\begin{array}{l}\text { 【塩浴軟室化】 : } 3750 \text { ショットで溶損 , カ } \\
\text { ジリのためピンを交換する } \\
\text { 【PCVD, (Ti, Al)N 系多層膜】 : } 11250 \text { ショッ } \\
\text { トの時点で溶損 , カジリ全くなし }\end{array}$ \\
\hline 熱間鍛造金型（マンドレル） & $\begin{array}{l}\text { 【自動車部品】 } \\
\text { 被加工材 } \\
\cdot \text { 材質 : SCM415 } \\
\cdot \text { 肉厚 : } 25 \mathrm{~mm} \\
\cdot \text { 温度 : } 1060 \sim 1100{ }^{\circ} \mathrm{C} \\
\end{array}$ & MH85(58HRC) & $\begin{array}{l}\text { 【未コート】: } 6000 \text { 個 (1 ロット分) } \\
\text { 【PCVD, (Ti, Al)N 系多層膜】: } 12000 \text { 個以上 } \\
\text { (2 ロット分を金型を取り替えないで加工 } \\
\text { 可能) }\end{array}$ \\
\hline アルミ押し出し金型 & $\begin{array}{l}\text { 【自動車部品】 } \\
\text { (コンデンサチュブ) } \\
\text { 被加工材 } \\
\text { •材質 : A1197 }\end{array}$ & 超硬合金 & $\begin{array}{l}\text { 【未コート】 : } 1 \mathrm{t} \text { まで加工可能 } \\
\text { 【CVD, TiN/TiCN/TiC】 : } 3 \mathrm{t} \text { まで加工可能 } \\
\text { 【PCVD, (Ti, Al)N 系多層膜】 : } 5 \mathrm{t} \text { まで加工 } \\
\text { 可能 }\end{array}$ \\
\hline
\end{tabular}




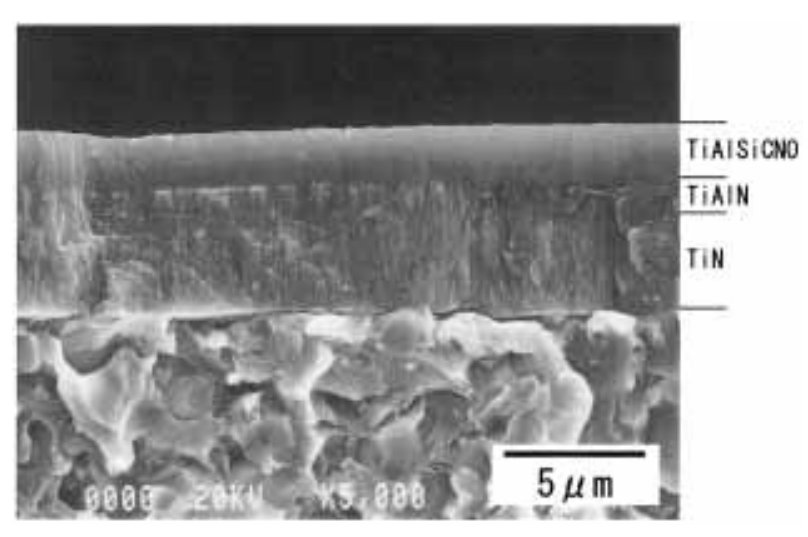

图 $7 \mathrm{TiN} / \mathrm{TiCN} / \mathrm{TiAISiCNO}$ 多層膜の断面 SEM 像 ${ }^{6)}$

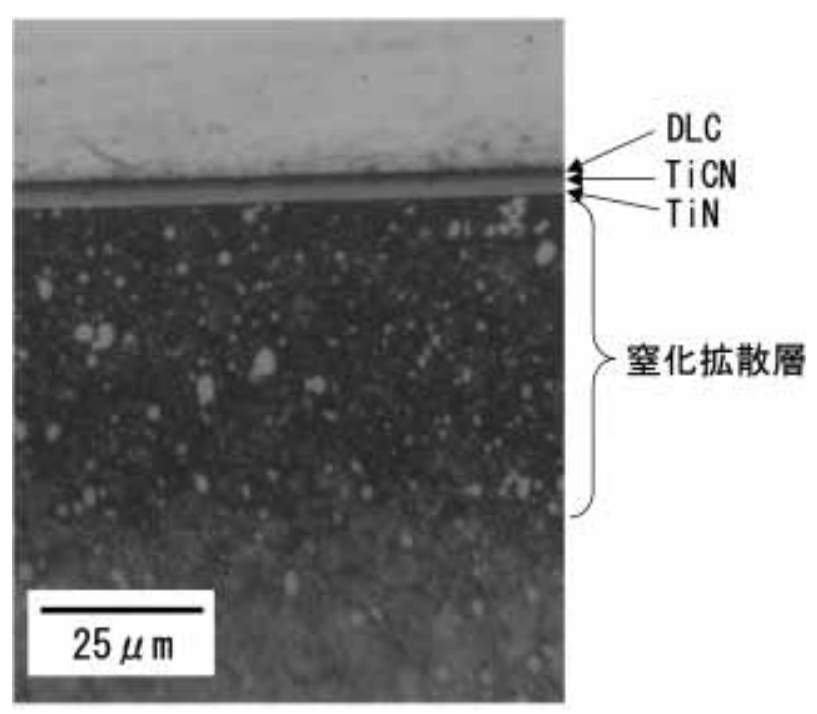

图 8 光輝プラズマ窒化+TiN/TiCN/DLC 複合処理した SKH51 の 断面組織 5)

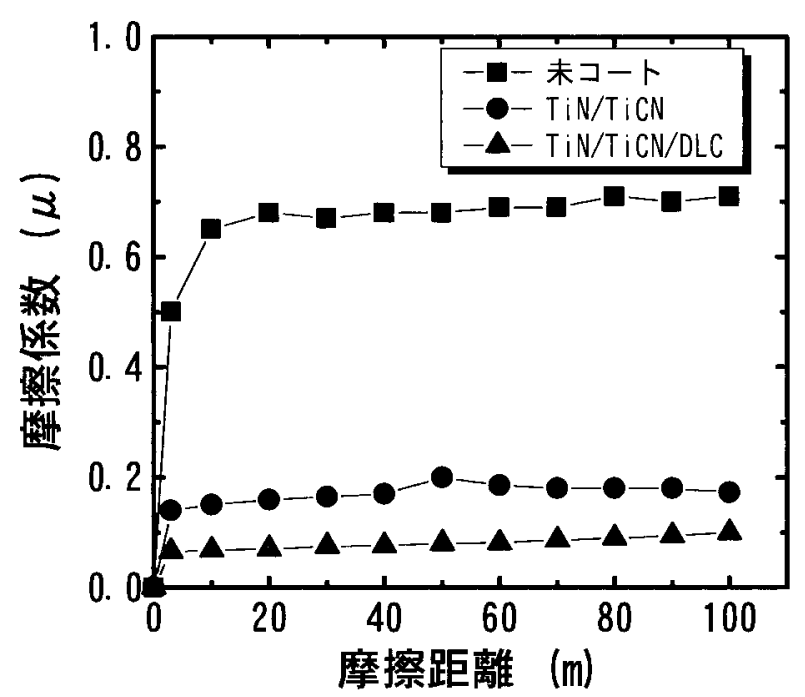

図 9 各試料の摩擦係数と摩擦距離との関係 ${ }^{5)}$ (ボール : SUJ2, 荷重 : $1 \mathrm{~N}$, 摩擦速度 : $30 \mathrm{~mm} / \mathrm{s}$, 大気中無潤滑)
ナノコンポジット膜はダイカスト,チクソモールディング における離型剤レス用として応用か始まっている。

DLC (Diamond-Like Carbon) 膜は, 高硬度, 高熱伝導 度, 高電気絶縁性などの優れた特性をもっている.パルス DC プラズマ CVD 装置 ${ }^{7)}$ は, 大面積, 複雑形状品への DLC 成膜がやりやすく，さらに，200 ㄷ下の処理温度である ため,低温焼戻し品や非鉄金属などの各種材料に応用可能 である。

冷間プレス金型の無潤滑加工の可能性を調査するため に,PCVD法によりSKH51に光輝プラズマ窒化+TiN/TiCN/ DLC 複合処理を施した試料を作製した，图８に光の試料 の断面組織 5) を示す . この場合, 窒化傾斜拡散硬化層は 基材の強化と膜との密着性を増し, 上層の膜構造は TiN,

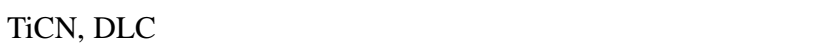
着性を確保している.图 9 に各試料の摩擦係数の变化 ${ }^{5)}$ 示す . PCVD 法による光輝プラズマ室化 + TiN/TiCN/DLC 多層膜被覆品は，摩擦係数が試験片の中で約 0.08 と最も 低く，また，ディスクおよびボールの摩耗も最も少なかっ た . 产のため，この膜は今後冷間プレスにおける無潤滑加 工の可能性を大きく開く膜として期待される .

また，アルミ合金の熱間鍛造用金型へは，耐熱性を改善 した DLC 膜を他のセラミックコーティングと組み合せた 拡散硬化層+TiN/TiAIN/DLC多層膜によりカジリに対して 拔群の効果を発揮している.

パルス DC プラズマ CVD 法による DLC(S-DLC) 膜の特 徵はつぎのようになる.

(1) 中間層, 各種拡散硬化層やイオン注入との複合処理, 金属や軽元素含有による膜内応力緩和により密着性が大 幅に向上可能 .

(2) PVD 法と違って処理圧力が高いため，膜のつき回り が良く 3 次元複雑形状品に応用可能 .

(3) 膜内応力を制御することにより $1 \mu \mathrm{m}$ から $10 \mu \mathrm{m}$ ま での厚膜まで処理可能 .

(4) 小物部品の大量処理から $300 \mathrm{~kg}$ までの重量物の処理 可能 .

(5) a-C:N, Me-DLC, DLN, a-CBNなどの炭素系新機能コー ティングも処理可能 .

\section{4 .おわりに}

最近の金型用表面処理技術の動向としては, 変形, 変寸 の観点から処理温度としては低温化に向かっており，ま た, 表面の薄膜だけで寿命向上を图るのではなく, 塑性変 形能を増したり，耐熱疲労強度を増したりすることができ る拡散硬化層の形成と表面皮膜との複合により寿命向上 
を図っている .さらに，表面の膜も潤滑性に優れた DLC 膜や耐熱性に優れた TiAIN 系膜を従来の TiN 膜と多層化 あるいは傾斜組成化によって密着性を確保して採用して いる。

各種のコーティング膜が開発されても，金型は 3 次元立 体の複雑形状品が多いため,プロセスによっては光の応用 には制限がある.PCVD 法は (拡散硬化層 + 硬質皮膜) と いう複合処理を 1 つの装置で真空を破らずに 1 回の工程で 行うことができる理想的なプロセスである．しかも，深穴 や狭スリットをもつ複雑形状した金型に対し，低温で密着 性の良い硬質皮膜をつき回り良く被覆できる.また，皮膜 も TiN, TiCN, TiAlN 系膜以外に次世代の TiAlSiCNO 系ナ ノコンポジット・スーパーハードコーティングや DLC 膜 により冷間プレス・鍛造加工の無潤滑化および温・熱間加 工の離型剤レス化に大きく貢献できるものと思われる .

$$
\text { (文 献) }
$$

1) 太刀川英男, 新井透:型技術, 5(1990), 10, 18.

2) 河田一喜:工業加熱, 37(2000), 3, 51.

3) 杉本義彦, 新井透:型技術, 9(1994), 5, 73.

4) 池永勝, 鈴木秀人:ドライプロセスによる超硬質皮膜の 原理と工業的応用, 日刊工業新聞社(2000).

5) 河田一喜:型技術, 18(2003), 12, 30.

6) 河田一喜:塑性と加工, 45(2004), 518, 7.

7) 河田一喜:表面技術, 53(2002), 11, 732 . 